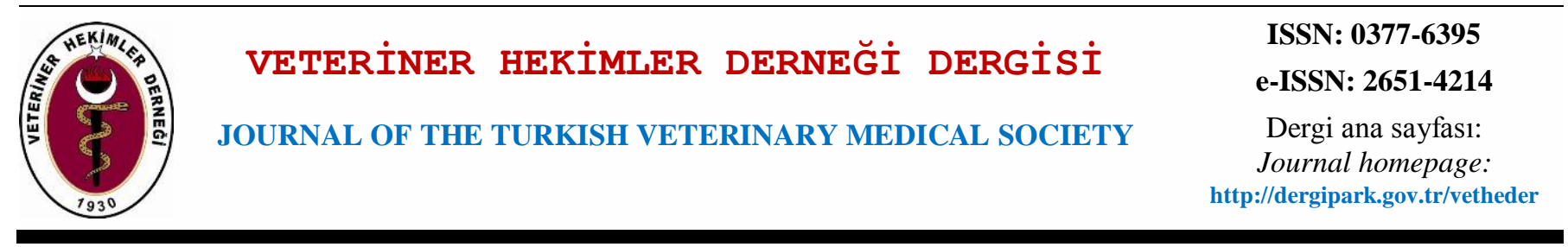

doi: $10.33188 /$ vetheder.475938

Araştırma Makalesi / Research Article

\title{
Çiğ süt örneklerinden izole edilen Staphylococcus aureus izolatlarında antibiyotik direnç özelliklerinin tespiti
}

\author{
Erhan KEYVAN ${ }^{\text {** }}$ \\ ${ }^{a}$ Burdur Mehmet Akif Ersoy Üniversitesi Veteriner Fakültesi Glda Hijyeni ve Teknolojisi Anabilim Dal, Burdur, Türkiye
}

\begin{abstract}
MAKALE BILGISI:
ÖZET:

ARTICLE

INFORMATION:

Geliş / Received:

29 Ekim 2018

29 October 2018

Kabul / Accepted:

04 Aralık 18

04 December 18

Staphylococcus aureus önemli bir gıda patojeni olup, tüm dünyada görülen gıda intoksikasyonları içerisinde üst sıralarda yer almaktadır. S. aureus'un gıda intoksikasyonlarında etkili olması yanında önemli bir diğer halk sağlığı problemi de farklı antibiyotiklere karşı şekillenen tekli veya çoklu antibiyotik direncidir. Bu çalışmada toplam 60 adet çiğ süt örneğinden izole edilen $31 \mathrm{~S}$. aureus izolatı antibiyotik direnç özellikleri yönünden analiz edilmiştir. İzolatların antimikrobiyel duyarlılıkları disk difüzyon yöntemi ile belirlenmiştir. Bu analiz, CLSI (Clinical and Laboratory Standarts Institute) tarafindan bildirilen yöntem esas alınarak, tetrasiklin, gentamisin, eritromisin, trimetoprim-sülfametaksazol, kloramfenikol, siprofloksasin ve klindamisin antibiyotik diskleri ile yapılmıştır. Analiz sonucunda gentamisin, eritromisin, tetrasiklin, siprofloksasin, klindamisin, trimetoprim- sülfametaksazol ve kloramfenikole karşı gelişen direnç sırasıyla $\% 3,33, \% 6,46, \% 16,12, \% 6,47, \% 80,64, \% 6,46, \% 16,13$ oranında tespit edilmiştir. Yetiştiriciler antibiyotik kullanımı konusunda bilinçlendirilmeli ve yasal bekleme sürelerine özen göstermelidir. Ayrıca yetkili otoriteler tarafından sütte antibiyotik varlığının tespitine yönelik kontroller düzenli olarak yapılmalıdır.
\end{abstract}

Anahtar Sözcükler: Antibiyotik direnci,

Çiğ süt,

\section{Detection of antibiotic resistance properties of Staphylococcus aureus isolated from raw milk samples}

S. aureus.

\section{ABSTRACT:}

Keywords:

Antibiotic resistance,

Raw milk,

Staphylococcus aureus is an important food pathogen and it is the main food intoxication agent all over the world. Also, $S$. aureus may cause a public health problem which is single or multiple antibiotic resistance against various antibiotics. In this study, thirty one $S$. aureus isolates which obtained from a total of 60 raw milk samples were analyzed for their antibiotic resistance properties. Antimicrobial susceptibilities of isolates were determined by disk diffusion method with tetracycline, gentamycin, erythromycin, trimethoprim-sulfamethoxazole, chloramfenicole, ciprofloxacin and clindamycin disks according to CLSI (Clinical and Laboratory Standarts Institute). Based on our results, antibiotic resistance of $S$. aureus isolates were detected in gentamycin, erythromycin, tetracycline, ciprofloxacin, clindamycin, trimethoprimsulfamethoxazole and chloramfenicole as $3.33 \%, 6.46 \%, 16.12 \%, 6.47 \%, 80.64 \%, 6.46 \%, 16.13 \%$, respectively. Dairy farmers should be educated about antibiotic use and comply with legal waiting periods in milk productions. Also, antibiotic residues in milk should be controlled regularly by local authorities.

\footnotetext{
* Sorumlu yazar / Corresponding author

e-posta adresi / e-mail address: erhankeyvan@ yahoo.com
} 


\section{Giriş}

Süt insanlar için önemli bir hayvansal gıdadır ve inek, koyun, keçi gibi hayvanlardan elde edilir. İnek sütü protein, karbonhidrat, yağ, aminoasitler, vitamin ve mineral içeriği sebebiyle beslenme için gereklidir (39). Süt önemli besleyici özelliği yanında yararlı ve zararlı bakteriler için de uygun bir üreme ortamıdır (29). Sağım koşulları, depolama ve süte uygulanan işlemler sonucunda sütte mikrobiyel kontaminasyonlar meydana gelebilir (14).

Staphylococcus aureus insan ve hayvanlarda; yara infeksiyonları, toksin kaynaklı bozukluklar (gıda zehirlenmeleri), endokarditis, osteomiyelitis, pnömoni, meningitis, beyinde apse gibi bozukluklar meydana getirebilir $(9,15,36,44)$. Ayrıca dünya çapında gıda kaynaklı zehirlenmelere yol açan bir patojendir (31). S. aureus süt ineklerinde klinik ve subklinik mastitise yol açarak süt ve süt ürünlerinde de kontaminasyonlar oluşturabilir $(1,7)$. $S$. aureus'un memeye transferinde; çevresel koşullar, sağım ekipmanları ve sağım yapan personelin kişisel hijyeni gibi faktörler etkilidir (21). Bazı türler hariç olmak üzere $\beta$-laktam, tetrasiklin, makrolid, linkosamid, novobiyosin ve kloramfenikol gibi çoğu antibiyotiğe duyarlıdır (42).

Antibiyotikler bakterilerle savaşan ilaçlardır ve hastalıkların tedavisi ile birlikte tarım ve hayvancılıkta da çeşitli amaçlar için kullanılmıştır. Bu yoğun antbiyotik uygulamaları ile birlikte bakteriler tarafindan antibiyotiklere karşı oluşturulan direnç, tüm dünyada önemli bir halk sağlığı problemi halini almıştır (46). Metisiline dirençli stafilokoklar, metisilinin klinik olarak kullanıma sunulmasından hemen sonra ortaya çıkmıştır. Metisiline dirençli $S$. aureus (MRSA) kaynaklı ilk salgın 1960 yılının başlarında Avrupa'da ortaya çıkmıştır. Bu tarihten itibaren MRSA dünya çapında önemli bir halk sağlığı problemi haline gelmiştir (10). Bakterilerde meydana gelen antibiyotik direnci global bir sorun olarak güncelliğini korumaktadır. Bu çalışmada, çiğ sütlerden $S$. aureus izolasyonu ve izolatlarda meydana gelen antibiyotik direncinin tespiti amaçlanmıştır.

\section{Gereç ve Yöntem}

Bu çalışmada, Burdur'da bulunan süt üretim çiftliklerindeki hayvanlardan farklı aylarda alınan toplam 60 adet çiğ süt örneği materyal olarak kullanıldı.

\section{Mikrobiyolojik analizler}

Analiz amaciyla soğuk zincir altında laboratuvara getirilen $50 \mathrm{ml}$ her bir süt örneğinden aseptik koşullarda homojen olarak seri dilüsyonlar hazırlandı ve Baird Parker/RPF (BP+RPF Oxoid, CM0961) agara ekimleri yapıldı (3). Agar üzerine ekimleri yapılan plaklar $35^{\circ} \mathrm{C}$ 'de $24-48$ saat süre ile inkübasyona bırakıldı. İnkübasyon sonrası besiyerinde tipik ve atipik koloniler seçilerek EDTA koagulaz plazma (Oxoid, R21052) ile tüpte koagulaz testi yapıldı. Koagulaz testi pozitif olan koloniler, Gram boyama, katalaz test, DNase aktivitesi, hemolitik özellikler ( $\beta$-hemoliz) ve mannitol fermentasyon testi yönünden analiz edildi. Bu testlerden fenotipik olarak pozitif olan koloniler $S$. aureus şüpheli izolatlar olarak seçildi $(20,37)$.

\section{PCR analizleri}

Fenotipik olarak S. aureus olarak saptanan suşlar, PCR tekniği ile doğrulandı. Bu amaçla öncelikle Akineden ve ark. (2) uyguladığ yönteme göre; izolatlar $18 \mu$ lizostafin içeren $180 \mu \mathrm{l}$ TE buffer (10 mmol Tris HCL/l, $1 \mathrm{mmol}$ EDTA/l, pH 8.0) içerisinde süspanse edilerek $37^{\circ} \mathrm{C}$ 'de 1 saat süre ile inkübasyona bırakıldı ve enzimatik olarak GeneJET Genomic DNA Purification Kit (Thermo Scientific, K0721) ile DNA ekstraksiyonu yapıldı.

İzolatlarda S. aureus'a spesifik nuc geni doğrulaması PCR yöntemi ile yapılmıştır. Bu amaçla Mehrotra ve ark. (30) ile Keyvan ve Ozdemir (25) tarafından bildirilen yöntemde bazı modifikasyonlar yapıldı. Standart PCR işlemi Lem ve ark. (27) tarafindan bildirilen primer çiftleri kullanarak ( 5'-ATA GGG ATG GCT ATC AGT AAT GT -3'/ 5'-GAC CTG AAT CAG CGT TGT CTT C- 3') $25 \mu$ l toplam hacimde $94^{\circ} \mathrm{C} 4 \mathrm{dk}$ ön denatürasyonu takiben, 35 siklus 
olacak şekilde; $94^{\circ} \mathrm{C}^{\prime}$ de $40 \mathrm{~s}, 54.5^{\circ} \mathrm{C}^{\prime}$ de $30 \mathrm{~s}, 72^{\circ} \mathrm{C}$ 'de $40 \mathrm{~s}$ ve son olarak $72^{\circ} \mathrm{C}$ 'de $10 \mathrm{dk}$ koşullarında analiz edildi. Amplifiye PCR ürünleri \% 1,5'lik agar jelde elektroforez işlemine tabi tutulduktan sonra görüntülenmiştir.

\section{Antibiyotik direnç özelliklerinin tespiti}

İzolatların antimikrobiyel duyarlılıkları disk difüzyon yöntemi ile belirlendi. Bu işlem, CLSI (Clinical and Laboratory Standarts Institute) tarafından bildirilen yöntem esas alınarak, Mueller-Hinton agarda (Oxoid, CM0337) tetrasiklin $(30 \mu \mathrm{g})$, gentamisin $(10 \mu \mathrm{g})$, eritromisin $(15 \mu \mathrm{g})$, sülfametaksazol-trimetoprim $(25 \mu \mathrm{g})$, kloramfenikol $(30 \mu \mathrm{g})$, klindamisin $(10 \mu \mathrm{g})$ ve siprofloksasin $(10 \mu \mathrm{g})$ antibiyotik diskleri kullanılarak yapıldı. Bu amaçla kültür muhafazası amaciyla bekletilen bakteriler Brain Heart Infusion Broth (Oxoid, CM1135) bulunan tüplere süspanse edilerek $37^{\circ} \mathrm{C}^{\prime}$ de zenginleştirilmiştir. Daha sonra zenginleştirilen bu kültür $0.5 \mathrm{McFarland}$ olarak ayarlandı. Zenginleştirilen broth kültürüne steril pamuk svap daldırılıp, tüp içerisinde süzülerek Mueller- Hinton agar yüzeyine inokulum svap tekniği ile yayıldı. Antibiyotik diskleri agar yüzeyi ile temas edecek şekilde ve merkezleri arasındaki mesafe 24 mm'den yakın olmayacak biçimde $150 \mathrm{~mm}$ çapında her bir petriye 5 disk olmak üzere yerleştirildi. Daha sonra $35-37^{\circ} \mathrm{C}^{\prime}$ de $18-24$ saat inkübasyona bırakılmıştır. İnkübasyon sonunda disk etrafindaki inhibisyon zon çapı CLSI'a göre değerlendirildi (12).

\section{Bulgular}

Yapılan analizler sonucunda toplam 60 çiğ süt örneğinden $31(\% 51,6)$ S. aureus şüpheli izolat elde edilmiştir. Disk difüzyon testi analiz sonuçlarına göre izolatlarda gentamisin, eritromisin, tetrasiklin, siprofloksasin, klindamisin, trimetoprim-sülfametaksazol ve kloramfenikole karşı gelişen direnç tablo 1'de gösterilmiştir.

Tablo 1: S. aureus izolatlarında antibiyotik direnç oranları.

Table 1: Antibiotic resistance levels of S. aureus isolates.

\begin{tabular}{lccc}
\hline & Dirençli & Duyarlı & Orta Düzey \\
\hline Gentamisin & $\% 3,33$ & $\% 96,77$ & \\
Eritromisin & $\% 6,46$ & $\% 51,61$ & $\% 41,93$ \\
Tetrasiklin & $\% 16,12$ & $\% 74,19$ & $\% 9,69$ \\
Siprofloksasin & $\% 6,47$ & $\% 77,41$ & $\% 16,12$ \\
Klindamisin & $\% 80,64$ & $\% 19,36$ & $\% 9,67$ \\
Trimetoprim- & $\% 6,46$ & $\% 83,87$ & \\
sülfametaksazol & $\% 16,13$ & $\% 83,87$ & \\
Kloramfenikol & & & \\
\hline
\end{tabular}

\section{Tartışma ve Sonuç}

Süt toplama tanklarında S. aureus varlığı farklı ülkelerde \%16,7-\%96,2 arasında olarak bildirilmektedir (8, 11, 18, 23, 24, 33, 43). S. aureus kaynaklı meme hastalıkları; süt veriminde azalma, sütte kalite düşüklüğü gibi ekonomik problemler ile birlikte çiğ süt ve süt ürünlerinde halk sağlı̆̆ açısından risk meydana getirebilir (13).

Jamali ve ark. (21) İran'da inek sütünden izole edilen $S$. aureus izolatlarında antibiyotik direnç özelliklerini; eritromisin için bu çalışmaya yakın bir değerde \%6,2, gentamisin için daha düşük oranda \%1,9, tetrasiklin için daha yüksek oranda $\% 56,2$, siprofloksasin için $\% 0$, klindamisin için daha düşük oranda $\% 13,6$, trimetoprim-sülfametaksazol için \%0, kloramfenikol için daha düşük oranda \%4,9 olarak bildirmiştir. Pakistan'da yapılan diğer bir çalışmada; izolatlarda gentamisine karşı şekillenen direnç bu çalışmaya göre yüksek oranda \%50 olarak şekillenirken trimetoprimsülfametaksazole dirençli izolat tespit edilememiştir (4). Obaidat ve ark. (34) Ürdün'de süt toplama tanklarından izole edilen izolatlarda meydana gelen antibiyotik direnç oranlarını bu çalışmada tespit edilen oranlara göre; gentamisin, klindamisin, eritromisin, siprofloksasisin için sırasıyla \%86, \%75,6, \%75,6, \%70,9 olarak daha yüksek bir değerde tespit etmiştir. Mısır'da yapılan bir çalışmada; süt ve süt ürünlerinden izole edilen metisiline dirençli S. aureus (MRSA) 
izolatlarında antibiyotik direnç oranları için bu çalışmaya göre daha yüksek oranlarda gentamisin için \%27,5, tetrasiklin için \%65,2, siprofloksasin için \%15,5, kloramfenikol için \%30,9, trimetoprim-sülfametaksazol için \%14 olarak bildirilmiştir (3). Can ve ark. (6) çiğ süt örneklerinden elde edilen izolatlarda antibiyotik direnç özelliklerini gentamisin, eritromisin, tetrasiklin, siprofloksasin ve kloramfenikol için sırasıyla $\% 0, \% 16, \% 28, \% 0, \% 0$ olarak tespit etmiştir. Bu çalışmada elde edilen eritromisin ve tetrasiklin sonuçlarına göre direnç oranın daha yüksek, diğer antibiyotiklerde ise daha düşük oranda kaldığı anlaşılmıştır. Sonuçlar arasındaki farklılıkta ülkeler arasındaki antibiyotik tercihlerinin etkili olduğu söylenebilir. Antimikrobiyel maddelere dirençli ve çoklu direnç geliştiren bakteri tiplerinin süt ve süt ürünlerinde bulunması önemli bir endişe sebebidir. Bu nedenle çoklu direnç geliştiren zoonotik etkenlerin tespiti ile süt ve süt ürünlerine kontaminasyonlarının engellenmesi için düzenli takiplerin yapılması gereklidir.

Mastitis, süt hayvanlarında neden olduğu tedavi giderleri nedeniyle ekonomik açıdan önemli bir hastalıktır (16). Ayrica meme bezlerinde oluşturduğu fonksiyon bozukluğu sebebiyle süt bileşiminde de değişiklikler meydana gelir (26). S. aureus süt hayvanlarında mastitis meydana getiren en önemli patojenlerdendir ve antimikrobiyel tedavi uygulanmasının temel nedenleri arasında bulunmaktadır $(5,17,35,38,40)$. Antibiyotiklerin yoğun şekilde kullanımı bakterilerde direnç gelişimine yol açabilir (28). Süt ineklerinde profilaktik ve mastitis tedavisi amaciyla $\beta$ laktam grubu antibiyotiklerin yaygın olarak kullanılması; süt ve süt ürünlerini MRSA açısından da riskli hale getirmektedir (41). Ayrıca MRSA da süt ineklerinde mastitis meydana getirebilir (19). MRSA'nın mastitisli sütlerde varlığını bildiren araştırmalardan Guimaraes ve ark. (18) \%48,3, Wang ve ark. (45) \%15,5, Jamali ve ark. (22) \%11,6, Moon ve ark. (32) $\% 2,5$ oranlarını bildirmiştir. MRSA sütlerde herhangi bir değişiklik meydana getirmeden gıda zincirine dahil olabilir (37). Gıda üretimi amacıyla yetiştirilen hayvanlarda gereksiz antibiyotik kullanımından kaçınılmalı ve bekleme sürelerine dikkat edilmelidir. Sütte MRSA varlığını bildiren çalışmalar da planlanmalıdır. Ayrıca bu çalışmada orta düzeyde dirençli olarak tanımlanan izolatların ilgili antibiyotiklere karşı tam bir direnç geliştirebilir. Bu nedenle izolatlarda orta düzeyde direnç gelişen antibiyotiklerin de takibinin yapılması gereklidir.

Antibiyotiklerin özellikle gıda üretimi amacıyla yetiştirilen hayvanlara tedavi amacıyla ve gelişim artırıcı olarak yoğun bir şekilde kullanılması insan sağlığı açısından önemli bir risk oluşturmaktadır. Süt ineklerinin tedavisinde kullanılan antibiyotikler sütte kalıntı meydana getirebilir. Bu nedenle süt ineklerinde meydana gelen hastalıkların tedavisinde etkili antibiyotiklerin seçilmesi gereklidir. Ayrıca çeşitli hastalıkların tedavisinde kullanılan antibiyotiklerin yasal bekleme sürelerine özen gösterilmelidir. Antibiyotik şüpheli sütlerin süt toplama tanklarına karıştırılmaması için toplama merkezlerinde süt alımı öncesi kontroller sıkı bir şekilde yapılmalıdır.

\section{Kaynaklar}

1. Adesiyun AA, Webb LA, Romain HT (1998): Prevalence and characteristics of Staphylococcus aureus strains isolated from bulk and composite milk and cattle handlers. J Food Prot, 61, 629-632.

2. Akineden Ö, Hassan AA, Schneider E, Usleber E (2008): Enterotoxigenic properties of Staphylococcus aureus isolated from goat's milk cheese. Int J Food Microbiol, 124, 211-216.

3. Al-Ashmawy MA, Sallam KI, Abd-Elghany SM, Elhadidy M, Tamura T (2016): Prevalence, molecular characterization, and antimicrobial susceptibility of methicillin-resistant Staphylococcus aureus isolated from milk and dairy products. Foodborne Pathog Dis, 13(3), 156-162.

4. Aqib AI, Ijaz M, Anjum AA, Malik MAR, Mehmood K, Farooqi SH, Hussain K (2017): Antibiotic susceptibilities and prevalence of Methicillin resistant Staphylococcus aureus (MRSA) isolated from bovine milk in Pakistan. Acta Trop, 176, 168-172.

5. Barkema HW, Green MJ, Bradley AJ, Zadoks RN (2009): Invited review: The role of contagious disease in udder health. J Dairy Sci, 92(10), 4717-4729.

6. Can HY, Elmalı M, Ergün Y (2017): Methicillin-resistant Staphylococcus aureus in milk from dairy cows with chronic mastitis. Eurasian J Vet Sci, 33(4), 255-259. 
7. Capurro A, Concha C, Nilsson L, Ostensson K (1999): Identification of coagulase positive Staphylococci isolated from bovine milk. Acta Vet Scand, 40, 315-321.

8. Chaalal W, Aggad H, Zidane K, Saidi N, Kihal M (2016): Antimicrobial susceptibility profiling of Staphylococcus aureus isolates from milk. Br Microbiol Res J, 13(3), 1-7.

9. Chambers HF, DeLeo FR (2009): Waves of resistance: Staphylococcus aureus in the antibiotic era. Nat Rev Microbiol, 7, 629-641.

10. Chambers, HF (1997): Methicillin Resistance in Staphylococci: Molecular and Biochemical Basis and Clinical Implications. Clin Microbiol Rev, 10, 781-791.

11. Chu C, Yu C, Lee Y, Su Y (2012): Genetically divergent methicillin-resistant Staphylococcus aureus and secdependent mastitis of dairy goats in Taiwan. BMC Vet Res, 8, 39.

12. Clinical and Laboratory Standards Institute (CLSI) (2013): M100-S23. Performance standards for antimicrobial susceptibility testing: 23rd informational supplement. Wayne, PA: CLSI.

13. Cortimiglia CEA, Bianchini V, Franco A, Caprioli A, Battisti A, Colombo L, Stradiotto K, Vezzoli F, Luini M (2015): Prevalence of Staphylococcus aureus and methicillin-resistant S. aureus in bulk tank milk from dairy goat farms in Northern Italy. J Dairy Sci, 98(4), 2307-2311.

14. De Silva SASD, Kanugala KANP, Weerakkody NS (2016): Microbiological Quality of Raw Milk and Effect on Quality by Implementing Good Management Practices. Procedia Food Sci, 6, 92-96.

15. Deurenberg RH, Stobberingh EE (2008): The evolution of Staphylococcus aureus. Infect Genet Evol, 8, 747-763.

16. Duarte CM, Freitas PP, Bexiga R (2015): Technological advances in bovine mastitis diagnosis: an overview. J Vet Diagn Invest, 27(6), 665-672.

17. Gomes F, Henriques M (2016) Control of Bovine Mastitis: Old and Recent Therapeutic Approaches. Curr Microbiol, 72, 377-380.

18. Guimaraes FF, Manzi MP, Joaquim SF, Richini-Pereira VB, Langoni H (2017): Outbreak of methicillinresistant Staphylococcus aureus (MRSA)-associated mastitis in a closed dairy herd. J Dairy Sci, 100, 726-730.

19. Haran KP, Godden SM, Boxrud D, Jawahir S, Bender JB, Sreevatsan S (2011): Prevalence and characterization of Staphylococcus aureus, including methicillin resistant Staphylococcus aureus, isolated from bulk tank milk from Minnesota dairy farms. J Clin Microbiol, 50(3), 688-695.

20. ISO (International Standart Office, 6888-1) (2003): Microbiology of food and animal feedingstuffs - Horizontal method for the enumeration of coagulase-positive staphylococci (Staphylococcus aureus and other species).

21. Jamali H, Paydar M, Radmehr B, Ismail S, Dadrasnia A (2015): Prevalence and antimicrobial resistance of Staphylococcus aureus isolated from raw milk and dairy products. Food Control, 54, 383-388.

22. Jamali H, Radmehr B, Ismail S (2014): Prevalence and antibiotic resistance of Staphylococcus aureus isolated from bovine clinical mastitis. J Dairy Sci, 97(4), 2226-2230.

23. Jørgensen HJ, Mørk T, Høgåsen HR, Rørvik LM (2005): Enterotoxigenic Staphylococcus aureus in bulk milk in Norway. J Appl Microbiol, 99, 158-166.

24. Kav K, Col R, Ardıc M (2011): Characterization of Staphylococcus aureus isolates from white-brined Urfa cheese. J Food Protect, 74, 1788-1796.

25. Keyvan E, Özdemir H (2016): Occurrence, enterotoxigenic properties and antimicrobial resistance of Staphylococcus aureus on beef carcasses. Ankara Üniv Vet Fak Derg, 63(1), 17-23.

26. Korhonen H, Kaartinen L (1995): Changes in the composition of milk induced by mastitis. 76-82. In: Sandholm M, Honkanen-Buzalski T, Kaartinen L, Pyörälä S (Eds.), The bovine udder and mastitis, Gummerus, Jyväskylä, Finland.

27. Lem P, Spiegelman J, Toye B (2001): Direct detection of mecA, nuc and 16S rRNA genes in BacT/Alert blood culture bottles. Diagn Microbiol Infect Dis, 41, 165-168. 
28. Levy SB (1992): The Antibiotic Paradox. How miracle drugs are destroying the miracle. Plenum Publishing, New York, NY.

29. Mehmeti I, Bytyqi H, Muji S, Nes IF, Diep DB (2017): The prevalence of Listeria monocytogenes and Staphylococcus aureus and their virulence genes in bulk tank milk in Kosovo. J Infect Dev Ctries, 11(03), 247-254.

30. Mehrotra M, Wang G, Johnson WM (2000): Multiplex PCR for detection of genes for Staphylococcus aureus enterotoxins, exfoliative toxins, toxic shock syndrome toxin 1 and methicillin resistance. J Clin Microbiol, 38, 10321035.

31. Meyrand A, Boutrand-Loei S, Ray-Gueniot S, Mazuy C, Gaspard CE, Jaubert G, Perrin G, Lapeyre C, Vernozy-Rozand C (1998); Growth and enterotoxin production of Staphylococcus aureus during the manufacture and ripening of Camembert-type cheeses from raw goats' milk. J Appl Microbiol, 85, 537-544.

32. Moon JS, Lee AR, Kang HM, Lee ES, Kim MN, Paik YH, Park YH, Joo YS, Koo HC (2007): Phenotypic and genetic antibiogram of methicillin-resistant staphylococci isolated from bovine mastitis in Korea. J Dairy Sci, 90, $1176-1185$.

33. Muehlherr JE, Zweifel C, Corti S, Blanco JE, Stephan R (2003): Microbiological quality of raw goat's and ewe's bulk-tank milk in Switzerland. J Dairy Sci, 86, 3849-3856.

34. Obaidat MM, Salman AEB, Roess AA (2018): High prevalence and antimicrobial resistance of mecA Staphylococcus aureus in dairy cattle, sheep, and goat bulk tank milk in Jordan. Trop Anim Health Prod, 50(2), 405-412.

35. Olde Riekerink RGM, Barkema HW, Veenstra S, Poole DE, Dingwell RT, Keefe GP (2006): Prevalence of contagious mastitis pathogens in bulk tank milk in Prince Edward Island. Can Vet J, 47, 567-572.

36. Papadopoulos P, Papadopoulos T, Angelidis AS, Boukouvala E, Zdragas A, Papa A, Hadjichristodoulou C, Sergelidis D (2018): Prevalence of Staphylococcus aureus and of methicillin-resistant S. aureus (MRSA) along the production chain of dairy products in north-western Greece. Food Microbiol, 69, 43-50.

37. Parisi A, Caruso M, Normanno G, L. Latorre R, Sottili A, Miccolupo R, Fraccalvieri G (2016): Prevalence, antimicrobial susceptibility and molecular typing of methicillin-resistant Staphylococcus aureus (MRSA) in bulk tank milk from southern Italy. Food Microbiol, 58, 36-42.

38. Peles F, Wagner M, Varga L, Hein I, Rieck P, Gutser K, Kereszturi P, Kardos G, Turcsanyi I, Beri B, Szabo A (2007): Characterization of Staphylococcus aureus strains isolated from bovine milk in Hungary. Int J Food Microbiol, 118, 186-193.

39. Quigley L, O'Sullivan O, Stanton C, Beresford TP, Ross RP, Fitzgerald GF, Cotter PD (2013) The complex microbiota of raw milk. FEMS Microbiol Rev, 37, 664-698.

40. Roberson JR, Fox LK, Hancock DD, Gay JM, Besser TE (1998) Sources of intramammary infections from Staphylococcus aureus in dairy heifers at first parturition. J Dairy Sci, 81(3), 687-693.

41. Sawant AA, Sordillo LM, Jayarao BM (2005): A survey on antibiotic usage in dairy herds in Pennsylvania. J Dairy Sci, 88, 2991-2999.

42. Seo KS, Bohach GA (2007): Staphylococcus aureus. 493-518. In: Doyle MP, Beuchat LR (Eds.), Food Microbiology: Fundamentals and Frontiers ASM Press, Washington.

43. Spanu V, Scarano C, Virdis S, Melito S, Spanu C, De Santis E (2013): Population structure of Staphylococcus aureus isolated from bulk tank goat's milk. Foodborne Pathog Dis, 10(4), 310-315.

44. Tauxe RV (2002): Emerging foodborne pathogens. Int J Food Microbiol, 78, 31-41.

45. Wang X, Li G, Xia X, Yang B, Xi M, Meng J (2014): Antimicrobial susceptibility and molecular typing of methicillin-resistant Staphylococcus aureus in retail foods in Shaanxi, China. Foodborne Pathog Dis, 11, 281-286.

46. Zaman SB, Hussain MA, Nye R, Mehta V, Mamun KT, Hossain N (2017): A review on antibiotic resistance: alarm bells are ringing. Cureus, $\mathbf{9 ( 6 ) ,} 1403$. 